\title{
Interpreting Islam in the Jewish State: Muftis and Ifta' in Israel
}

\author{
Muhammad Al-Atawneh \\ Department of Middle East Studies, Ben-Gurion University of the Negev, Beer-Sheva, Israel
}

\section{Email address:}

alatawnh $@$ bgu.ac.il

\section{To cite this article:}

Muhammad Al-Atawneh. Interpreting Islam in the Jewish State: Muftis and Ifta' in Israel. Advances in Sciences and Humanities. Vol. 6, No. 1, 2020, pp. 9-17. doi: 10.11648/j.ash.20200601.12

Received: October 3, 2019; Accepted: November 14, 2019; Published: January 13, 2020

\begin{abstract}
Islam is the religion of the majority of Arab citizens in Israel. According to a report issued by Israeli Central Bureau of Statistics, there are 1.2 million Muslims in Israel, comprising about $80 \%$ of the Arab population in the country. Over the past four decades, Islam has become an important factor in the political and socio-cultural identity of the Arab minority; the number of Muslims in Israel who define their identity first and foremost in relation to their religious affiliation has steadily increased. This article studies the authority, ideologies and legal methods and mechanisms used by muftis practicing ifta' in the State of Israel when interpreting Islam for the resident Muslim minority. Key questions are: Who serve as the primary religious authorities for Muslims in Israel? Does a unique 'Israeli-Islam' exist? The present research found that the evolving Islamic law of minorities in Israel is much less developed than it is in the West; as such, one cannot yet identify Islam in Israel as 'IsraeliIslam,' as having its own distinct nature (as in the case of 'Euro-Islam'). To date, there seems to be no single locus of Islamic religious authority in Israel; multiple groups claim to speak on Islam's behalf. As such, there is religio-political fragmentation amid the Muslim community in Israel, each group seeking to create its own religious authority: CIS of the al-Qasemi Sufi Order; ICIF of NIM and, finally, the ad-hoc SIM ifta' committees. To date, none of these ifta' agencies in Israel has been able to formulate, authorize and apply a code of Islamic minority law in Israel, and they continue to rely heavily on foreign Islamic religious authorities. Israeli Muslims continue to maintain strong ties with the regional socio-cultural and religious space and with their peers in the Muslim-Arab world. Israeli ifta' agencies tend to adopt and adapt work methods used by foreign, regional Islamic religious authorities and to accept, as is, or adapt many of their opinions/decisions.
\end{abstract}

Keywords: Muftis, Ifta', Authority in Islam, Religious Minorities

\section{Introduction}

This article investigates religious agencies that issue fatwas, paying special attention to their recognition as valid authorities and to the means by which they interpret Islam for the Israeli-Muslim minority. Two crucial questions are: Does a distinct 'Israeli-Islam' exist? Is there a primary religious authority recognized by the Muslim population of Israel? Note that Islam is the religion of the majority of Arab citizens in Israel. According to a report issued by Israeli Central Bureau of Statistics, there are 1.2 million Muslims in Israel, comprising about $80 \%$ of the Arab population in the country [1]. Over the past four decades, Islam has become an important factor in the political and socio-cultural identity of the Arab minority; the number of Muslims in Israel who define their identity first and foremost in relation to their religious affiliation has steadily increased [2]. Muhammad Amara, an Israeli sociologist, notes that the Arab minority in Israel places great emphasis on Islam as a factor in their identity, more than during any other period [3]. The increased Islamic impact on Muslims in Israel is manifested by a sharp rise in the number of religious associations, mosques, cultural centers, schools and academic religious institutions, such as al-Qasemi Academic College of Education in Baqa alGharbiyya and the Da'wa College for Islamic Studies in Umm al-Fahm. An increasing number of Muslim-Israeli students choose to study Islam in the West Bank, Egypt, Jordan, Turkey and Malaysia.

Despite modernization, Islam is still a very important factor in the formulation of the Muslim community's ethical and social norms. Islam affects the behavior of the Muslim minority in Israel and Islamic values often shape behavioral 
standards. This impact is evidenced by the degree to which the Muslim community is committed to the Shari 'a as a basis for its normative behavior (religious practice) and its reliance on religious agencies established by the Islamic Movement (IM) and the State of Israel.

\section{Practicing Ifta' in Israel}

In Israel, there are three major agencies for issuing fatwas: (1) The Center for Islamic Studies, Manuscripts and Issuing Religious Opinions (CIS), also known as the Ifta' Center at al-Qasemi College in Baqa al-Gharbiyya; (2) the Islamic Council for Issuing Fatwas (ICIF) in Nazareth; and (3) the ad-hoc ifta' committees of the southern branch of the Islamic Movement (SIM). These agencies mostly tend to follow the current practice of collective ifta' [6]. Thus, new Islamic religious institutions have emerged in the West, such as the Islamic Society of North America (ISNA) and the European Council for Fatwa and Research (ECFR), founded in 1982 and 1997, respectively [7]. These institutions have contributed to the creation of a new category of Islamic law the religious law of minorities (fiqh al-aqalliyyat) that seeks to balance traditional interpretations of Islamic law with the demands of everyday life in non-Muslim countries [8].

\subsection{The Center for Islamic Studies (CIS)}

CIS was founded in 2005 by the Khalawati Sufi Order in Israel in Baqa al-Gharbiyya. The Khalawati Sufi Order in Israel was established in the late Ottoman period by the alQawasmeh family from Hebron and is still led by members of this family [9]. In 1989, this Sufi order established a college of Shari'a and Islamic Studies, bearing the family name; in 1993, the college was certified by the Israeli Council for Higher Education. Today, it has more than 3,000 students and 150 faculty members, including both ArabIsraeli and Jewish-Israeli lecturers. Students are awarded degrees in seven fields: Islamic Studies; Arabic Language and Literature; English Language and Literature; Mathematics and Computers; Early Childhood Education; Special Education; and the Sciences [10].

CIS functions as an integral part of al-Qasemi College's Department of Islamic Studies [11]. Among its major goals and objectives, as stated on its website, are the following:

1. To spread Islamic teachings and ideologies.

2. To investigate important modern-day issues.

3. To issue collective fatwas in response to problems faced by Muslims, locally and internationally...

4. To produce Islamic research and studies that address emerging issues.

5. To disseminate the tolerant nature of Islam as a middle path (wasatiyya), neither extremist nor contemptuous.

6. To introduce Islamic civilization and its contribution to non-Muslims and humanity.

7. To urge researchers to address modern-day issues: educational, social, economic, and medical, and to clarify Islamic attitudes toward them.

8. To foster ties between CIS and other local and international fatwa agencies.

9. To develop and enrich CIS' library by adding new research and publications.

10. To publish select fatwas [12].

According to CIS Chairman, Shaykh Khaled Mahmud, the Center aims to serve the Muslim community in Israel by responding to their practical, real-life queries. He claims that thousands of fatwas have been issued in response to questions received from Muslims across Israel, although most these fatwas were issued orally and are undocumented. The CIS issues fatwas in an attempt to suit Islamic law to the local conditions of the Muslim minority in $21^{\text {st }}$ century Israel, in a way that preserves the delicate balance between the divergent groups within the Muslim community [11].

CIS serves not only as an ifta' center, but as an Islamic research center that promotes academic studies on religious issues, taking into consideration the modernization process undergone by the Muslim minority in Israel. Shaykh Mahmud stated:

The age in which we live now is an era of scientific and technical challenges. No nation can compete in this regard if it does not use all its scientific and intellectual energies to build a healthy society and to achieve the intended development [11].

CIS publishes religious studies dealing with problems encountered in modern society and issues periodic bulletins, such as Majallat Dirasat Islamiyya (Magazine of Islamic Studies). In addition, CIS sponsors public lectures, conducts seminars and conferences, and utilizes modern media and communications in order to reach a wide audience [13].

The legal methodology adopted by CIS is similar to that of ICIF, i.e., it does not confine itself to a certain Sunni school of thought (madhhab) and applies 'preponderance' (tarjih) as a determining criterion. The following are its sources and methods, as presented on the CIS website:

1. Adoption of Sunni legal theory and different methods of argumentation (turuq al-istidlal) from various madhhabs, especially that of determining the 'preponderance of opinions' (tarjih).

2. The sources for issuing fatwas must be those agreed upon by the major Sunni madhhabs.

3. Controversial sources of legislation [often the ancillary legislative sources based on Muslim legal principles] may be: analogy (qiyas); seeking good will or striving for betterment for all (istihsan); public interest (almaslaha al- 'amma); and/or local custom ('urf) - all of which consider real-life situations in the spirit of Islam and public welfare.

4. Reliance on attested Islamic juridical sources.

5. Adherence to the legal principle of 'the prevention of damage is preferable to the promotion of benefit', while publishing fatwas that simultaneously accommodate both the current situation of Muslims [in Israel] and the spirit of Islam, by means of a correct interpretation of the intentions of the Shari a [14].

Clearly, CIS intends to function as a religious authority that applies the Shari'a to the actual situation of the Muslim 
minority in Israel, as indicated by the adoption of a flexible methodology (item 5 above), and to serve as a body to which Muslims in Israel can turn with their religious queries.

Yet, the Sufi nature of CIS suggests another methodology for attaining authority, resembling Richard Friedman's notion of "being an authority" [15]. That is, the Sufi master/disciple authority structure (shaykh/murid) is manifested by the full submission of the latter to the will of the former, as total obedience to all the master's orders and advice. In traditional Sufi teachings, disciples must abandon themselves to the Shaykh and his followers "like a dead body to its washer" [16]. Shaykh Mahmud describes the centrality of dialogue and recourse to the Sufi Shaykh as follows:

Beneficence and Sufism are in fact synonymous and one can never truly grasp them unless in the company of divine and perfect masters. The master who calls for the truth is the one who enhances the path of Allah insightfully. He is also the one who calls on Muslims to follow the teachings of Prophet Muhammad ... Al-Suhrawardi legitimized the master status based on the saying of Prophet Muhammad: "Among His servants, Allah loves most those who endeavor to make Allah love his servants and make Allah's servants love Allah and walk on land giving advice to people" [17].

As such, the absolute loyalty of followers to their charismatic spiritual leader forms the mainstay of this interrelationship, as embodied by Sufi 'etiquette' ( $a d a b)$. The early followers of the Prophet, Muhammad's Companions, serve as role models for Sufi masters:

The rule of the [Sufi] master is to invite people to God on behalf of the prophets and to purify their souls of their arrogance, as said by the late Shaykh 'Abd al-'Aziz alDabbagh, so that they may be able to bear the secret of knowledge. The Shaykhs are soldiers of Allah who guide the disciples and those who seek knowledge, and renew the activity of faith in their age, and rekindle the light of the message of Prophet Muhammad throughout time... This is what Prophet Muhammad meant by "the scholars are the heirs of the prophets." Since the Shaykh's job is so important, we must treat him most politely, if we intend to arrive at the highest level of spiritual perfection. The Companions reached the highest levels in the company of Prophet Muhammad by being well-behaved and most respectful of him [18].

Islamic Sufism is a science which adheres to the basic sources of Islam. Sufism focuses on etiquette; each state and station has its own special etiquette. Those who abide by the etiquettes of the times may arrive at the status of the Sufi 'knower-of-God'. Yet, one who abandons these etiquettes becomes distant from that status, rejected, mistakenly thinking that he/she is close and accepted. It has been said, "A person who is shackled by genealogy is freed by etiquette." Some Sufis said: "A person who has no etiquette can never walk the path and will never arrive at the desired destination [18].

Etiquette with the master involves total obedience and submission to his commands and prohibitions, venerating and respecting him, and never objecting to his spiritual training. Disciples should respect him as an assiduous person who is most qualified to guide. They should initiate service to him, seek his counsel, as much as possible, tolerate his educational positions and repeat none of the Shaykh's sayings, except those that can be tolerated by ordinary people [18].

Indeed, the local CIS community mainly consists of members of the Khalawati Sufi Order. To be 'khalawati' means to belong to one of three circles. The first of these is a restricted, elitist circle of students, forming the core of the Sufi Order. The second, larger middle ring consists of followers seeking proximity and the blessing rituals in the public sphere, without being required to change their personal lifestyles. Their affiliation is partial and uneven, but they may experience the full scope and significance of Khalawati Sufism when the Shaykh Guide is present. The third, outer ring is composed of believers who are able to see the spiritual Shaykh Guide without taking an active part in the rituals.

CIS seems to take much softer positions in its fatwas than those expressed by ICIF. For example, in regard to a fatwa concerning the taking of a bank mortgage for the construction of a family home, Shaykh Mahmud states that Muslims in Israel may take a mortgage, since the Islamic principles of 'public interest', 'preventing evil' and 'necessity overcoming a prohibition' are met [11]. He explains that the housing situation for Muslims in Israel is very bad. There is little land allocated by the state for residential construction and housing for young Muslim families, as well as an insufficient supply of apartments for rent. Muslim society cannot tolerate such crowded living conditions in the long run. Thus, the issue of building a family home has become a 'necessity' without which Muslims find it very difficult to start their families. The Shaykh adds that this ruling is intended only for Israeli Muslims, due to the specific local circumstances in Israel [11].

\subsection{Islamic Council for Issuing Fatwas}

As of 1996, informal ifta' was being practiced by the northern branch of the Islamic Movement (NIM), by means of its newspaper Sawt al-Haqq wa'l-Hurriyya, in the form of published responses to public queries [19]. In 2002, ICIF was established by NIM in an attempt to institutionalize the practice of ifta', created "as a response to the large number of urgent issues and developments in [Islamic] jurisprudence and to resolve repeated conflicts in jurisprudential views and reduce the level of chaos in some cases" [19]. Previously, the Muslim minority in Israel had received fatwas via satellite broadcasts and correspondence with regional and international Muslim jurists. However, those jurists were often unfamiliar with the unique situation of the Muslim minority in Israel and their answers sometimes failed to address the actual needs of the Israeli Muslim community [20].

ICIF presented itself as an alternative local ifta' agency, prepared to address the various challenges faced by the Muslim minority in Israel on a daily basis, as may be seen in its goals and objectives:

1. To answer questions posed by the public, while taking 
into consideration the actual, current circumstances of the Muslim minority.

2. To make Islamic law more easily accessible and intelligible to the public.

3. To address innovations and developments in daily life that challenge the Israeli Muslim minority through communication with specialized regional and international Islamic bodies.

4. To address recent religious controversies, known as 'fatwa chaos' (fawda al-fatwa).

5. To establish a unified methodology for dealing with religious issues related to the Muslim minority in Israel.

6. To bring different points of view closer together, based on the Qur'an, the Sunna and the four Sunni legal schools (madhhabs).

7. To support Muslim scholars with regard to general public issues of concern to the Muslim nation (umma) [19].

ICIF aspires to be the leading religious authority for Muslims in Israel. In its "Vision" statement, the founders clearly declared that such authority was to be achieved by "the expansion of ICIF's influence over all segments of society and schools of thought within the Muslim minority in Israel... [19]." To that end, ICIF proposed the local establishment of "mini-committees in community centers all over the country subordinate to ICIF; and [in the international sphere] to attain membership in the Islamic International Fiqh Council [19].

ICIF targets a wide audience from the various strata of the Muslim minority in Israel. Queries may be submitted in person, by telephone, in writing, or via the ICIF website. It posts weekly schedules with the names and contact information of local muftis. Each contact list includes the names of female religious counsellors who answer women's queries [21]. All ICIF's answers are both posted directly to the inquirer and published, in most cases, in the weekly newspaper, Sawt al-Haqq wa'l-Hurriyya, in a section entitled: "Ask the Sages", or in the monthly magazine, Ishraqa (Sunrise), or on the ICIF website or Facebook page [22]. In 2005 and 2012 more than 11,000 fatwas were compiled and published in two volumes, under the title Fatawa al-Majlis al-Islami li'l-ifta' [24]. Other publications have been dedicated to local and general Islamic issues, including: Fatawa Maqdisiyya, on issues relating to the alAqsa Mosque (2013) and Mukhtarat Fiqhiyya fi al-Hajj wa'l'Umrah, on issues relating to pilgrimage (2013). In 2015, two new texts were published: Fatawa al-Mar'a al-Muslima, a collection of fatwas for Muslim women and Fatawa hira' hawla Ahkam al-Qur'an al-Karim wa-Adabihi, a collection of fatwas on the Qur'an. In addition, ICIF holds conferences to discuss Islamic issues in the socio-cultural and religious spheres. One such conference, held on November 11, 2013 in Kafr Kanna, was entitled: A Conference Regarding Islamic Legal Opinions Relating to Worship in the Winter Season [25].

ICIF does not limit itself to a specific Sunni tradition when applying the Islamic principle of 'preponderance' (tarjih) as a determining criterion [26]. In ICIF's words: "When issuing written and oral fatwas, ICIF relies on the four schools of thought (madhhabs) and departs from their teachings only in cases of private or public necessity ..."[27]. That is to say, ICIF supports inter-madhhab interpretation and rejects the notion of strict adherence to a specific madhhab, on the grounds that there is no reason for a Muslim to be constrained by a particular legal doctrine. According to ICIF, if a creative interpreter discovers the validity of an opinion established in another madhhab, he may follow it. It is not appropriate to privilege one's madhhab over another if the other's position is more just. An interpreter should always strive to attain justice for its own sake. Therefore, a seeker of justice, though he identifies himself with a particular legal school, should not abide by it when the truth lies elsewhere [19].

When an issue is raised for which there is no precedent in the four schools, ICIF prepares and/or utilizes relevant new Islamic research studies. ICIF also quotes existing decisions "... by one of the Islamic international councils, primarily the Fiqh Council of the Organization of the Islamic Conference [i.e., the International Islamic Fiqh Academy in Jeddah].” It also accepts certain decisions from other fatwa councils in the Muslim world, such as the Egyptian Agency for Issuing Fatwas (Dar al-Ifta' al-Masriyyah); The Palestinian Council of 'Ulama' in the Diaspora (Hay'at 'Ulama' Filistin fi'lKharij); and The Permanent Committee for Scientific Research and Legal Opinions (al-Lajna al-Da'ima li'lBuhuth al- 'Ilmiyya wa'l-Ifta') in Saudi Arabia [28].

ICIF fatwas include the following elements: a statement explaining the reason for its issuance, the name of the inquirer, the question, the argument and, finally, the opinion. In general, the argument starts with Qur'anic precedents, followed by relevant Hadiths and quotations from Islamic legal texts. Sometimes, fatwas are presented at meetings without any argument. Each fatwa is assigned a serial number and is signed by ICIF [19]. By not confining itself to a certain madhhab, ICIF strives to utilize the rich Islamic legal tradition in the broadest sense, in an effort to adapt the legal system to the challenges of modern life. ICIF frequently references all four madhhabs in its fatwas. When acknowledging occasional discrepancies between the madhhabs, ICIF advocates for 'moderation' or choosing 'the median path' (wasatiyya) in regard to tradition: [29].

ICIF follows the wasati methodology (manhajiyyat alwasatiyya), while avoiding extremism, fanaticism and intolerance, when issuing fatwas. It bases decisions on the four prestigious, centuries-old, madhhabs, while considering local circumstances and norms... [19].

Though ICIF has ostensibly chosen wasatiyya as its methodological path, it sometimes presents a conservative opinion in fatwas on certain subjects, for instance the prohibition on music. In response to one query ("What is the Islamic rule about music?"), ICIF answered as follows:

Listening to musical instruments, like the oud, violin, clarinet, flute and other wind instruments, is forbidden 
(haram). This is the view the majority of scholars, such as Ibn al-Qayyim, al-Suyuti, al-Turtushi and others belonging to various madhhabs, e.g. Shafi 'i, Maliki and Hanbali. It is also the view of a number of contemporary scholars including: Dr. Omar Suleiman al-Ashqar, Muhammad Hamid, Abdul Aziz Bin Baz, The Standing Committee for Scientific Research and Issuing Fatwas in Saudi Arabia, and others... [30].

The positions of Muslim scholars on music fall into two broad groups. The dominant group holds that most music is permissible, in principle, so long as the contents and performance are in accordance with Islamic legal and ethical norms. For this group, music is merely inoffensive 'noise'. However, the contents of a song and the activities associated with its music must be consistent with Islamic norms [31].

The second group of scholars, best represented by the Wahhabis, prohibits most entertainment involving music. For the Wahhabis, almost all types of music are forbidden, since they are thought to encourage temptation and other immoral practices. This prohibition includes attendance at parties and musical events and the airing of instrumental music and singing, even in the official Saudi media [31]. In this instance, ICIF has adopted the conservative position, while ignoring the dominant, liberal one.

ICIF's conservative approach is also manifested in fatwas relating to women and gender. For example, sexual relations between a man and a woman who have concluded a marriage contract ('aqd nikah; i.e., who are officially engaged), but who are not yet living together as husband and wife, are forbidden. This position is at odds with that of two madhhabs that allow marital intercourse once the marriage contract has been validated [32].

Furthermore, ICIF forbids Muslim women to completely undress before other women, although most Islamic madhhabs only restrict 'nakedness' from the navel to the knee [35]. ICIF acknowledges this more liberal position, but states: "This rule is embodied in the authentic traditions, but is not applicable in our time..." [34].

ICIF also holds that intermarriage between a Muslim man and a Christian or Jewish woman is to be avoided, since it may cause social tension or dysfunctional family life. One fatwa specifically explains why such interfaith marriages should be avoided and provides instruction on how to select an appropriate partner [35]. This position is at odds with opinions found in most other madhhabs, which do permit marriages between Muslims and non-Muslims, particularly the "People of the Book" (ahl al-kitab, i.e., Jews and Christians).

ICIF considers ikhtilat (i.e., the intermingling of men and women) to be the major cause of temptation, exacerbated when a woman remains alone with a non-mahram (not consanguine, i.e., marriageable) man, a situation known as khalwa. Thus, ICIF forbids mixing and khalwa. One exemplary ICIF fatwa reads:

Query:

What is the Islamic rule regarding the intermingling of men and women?

Answer:
In principle, a Muslim must avoid mixing as much as possible, because of the improprieties and temptation that may result from it ... Yet, if intermingling of the two sexes is inevitable, as in schools and colleges in our country [Israel], the following conditions must be maintained. Women must:

1. Dress in accordance with the Islamic dress code, avoiding perfume, dyes and other forbidden accoutrements.

2. Lower their gaze (ghadd al-basar) when necessary.

3. Commit to [Islamic] speech and seating ethics...

4. Never remain alone with a marriageable non-relative (khalwa).

5. Married women must secure the permission of their husbands and single women must secure that of their guardians.

We emphasize the need for gender-separate education in schools, colleges, and other institutions, especially those of the Islamic Movement... If such gender separation has not been enacted, special classroom seating arrangements must be made, such that male students sit in front and female students sit behind them. Gender-separation must be maintained when entering or exiting classes, as well as elsewhere in these colleges and schools... [36].

According to Islamic law, legal khalwa (khalwa shar 'iyya or sahiha) is permissible for engaged couples with a marriage contract ('aqd nikah) and between close blood relations (mahram), such as fathers, grandfathers, brothers, and uncles, and unmarriageable female relatives. Any other social contact (khalwa) between the sexes is considered illicit. As yet, there is no consensus among contemporary Muslim jurists on the legal meaning and implications of khalwa in the modern context [37]. Currently, most Islamic scholars consider the intentional, clandestine meeting between a woman and a nonmahram man to be illicit khalwa. One group of muftis (a fatwa team) on the well-known Islamic website, "Islamweb," defined illicit khalwa as follows:

...When a non-mahram man sits in private with a woman and the two of them are not visible to the public... However, talking to or meeting with one or more women in public does not qualify as illicit khalwa [38].

Similarly, Egyptian Shaykh Yusuf al-Qaradawi, Chairman of the International Union of Muslim Scholars, asserts that men and women may meet in public places, so long as they behave in accordance with Islamic ethics and norms. In his view, contacts between men and women are not entirely forbidden and may be allowed when their purpose is noble and lawful, as, for example, in order to acquire beneficial knowledge, engage in charitable projects, perform obligatory jihad or any other good deed that requires the efforts and cooperation of both sexes [39].

Despite its stated preference for wasatiyya methodology, ICIF takes a more conservative approach to khalwa, than do the aforementioned authorities. It finds illicit khalwa manifested in almost any contact between a woman and a non-mahram man, regardless of whether they are visible to the public or not, based on the Prophetic tradition: "When a man and a woman remain alone in private, the third party is 
always the Devil" [40]. ICIF also holds conservative positions on intermarriage and music, while paying little attention to the unique circumstances of the Muslim minority in Israel.

\subsection{Ad-Hoc Committees for Ifta': The Southern Movement (SIM)}

Unlike the cases of ICIF and CIS, the practice of ifta' by SIM has never been formalized and is implemented by adhoc committees. The head of SIM, Shaykh Hamad Abu $\mathrm{Da}$ 'abis, says that this situation stems from certain financial and logistic considerations; however, he stresses that the creation of a southern ifta' center is only a matter of time [41]. According to him, there have been some previous attempts to do so by establishing al-Hiwar College in Tira (2001) and the Council of Fatwa and Islamic Studies in Kafr Qasim; however, they no longer exist. In the meantime, SIM seeks to reach decisions on current religious issues by convening ad-hoc committees on-demand [41]. Fatwas may also be given individually or sporadically to those who query religious scholars and members of SIM, such as certain imams in mosques, as long as the responding imam has sufficiently studied the issue in question [41].

The religious authority of SIM may even be supported by foreign scholars and religious institutions across the Islamic world. SIM leaders rely on various agencies and authorities, including the Grand Mufti of the Palestinian Authority, whose fatwas may be relevant to the Muslim minority in Israel [41]. In principle, SIM is also not committed to one particular Islamic school of thought; like ICIF and CIS, SIM recognizes all four Sunni madhhabs, adopting moderate attitudes from them that suit the current reality faced by the Muslim community in Israel.

One of the most prominent examples of SIM ad-hoc ifta' is a fatwa regarding participation in the Knesset (Israeli Parliament) elections. This fatwa was an updated version of a preliminary ruling made by SIM leaders during the 1996 Knesset elections. Shaykh 'Abd Allah Nimr Darwish (19482017), former Head of SIM, made clear references to developments in Israel and the region regarding the Muslim minority in Israel. The revised fatwa was signed by the Committee of Fatwa and Islamic Studies [now defunct], which authorized Muslim participation in Israeli elections to the Knesset. That Committee, aware of the Islamic debate on the issue, argued that, after reviewing the positions of Islamic scholars for and against participation in the elections, it had reached the conclusion that there is no contradiction between participation in political life and the call to Islam. Even if political participation might involve some 'harm', it would be minimal and would not violate the greater principles of Islam; any minor damage would be offset by the benefits of active participation. In such cases, Islam chooses the lesser of the two evils and the greater good. Participation in Israeli elections, as dictated by the situation, is not a concession made to 'oppressors,' whereas refraining from active participation might leave the Muslim community solely in the hands of said 'oppressors.' SIM chose the first option, recognizing that such participation is both possible and permissible, thanks to the flexibility in Islam [42].

This significant fatwa presents SIM's pragmatic approach. Acting in accordance with this fatwa, the indigenous Muslim minority in Israel managed to highlight their presence in their homeland, while ignoring the existence of a legitimate Israeli establishment (and avoiding the conflicting state symbols and its definition as a Jewish/democratic state). The fatwa states that the issue of participation in national elections is based on two components. The first relates to political action, which is part of a wide range of activities with one primary goal - to preach Islam for the betterment of individuals and society and to maintain their identity and land. Therefore, there is no conflict between legislative work and SIM's community action. Moreover, SIM claims that its participation in the Israeli political system yielded positive results and achieved long-term goals: to serve the Muslim community in Israel; to promote the welfare of Muslim individuals and Muslim society; to protect the Temple Mount mosques; and to accumulate assets.

The second component is based on the Islamic principle of 'public interest' (maslaha 'amma). In this regard, participation in the elections is a tool, a means to combat racism and oppressive policies enacted by the Israel Government. Active political participation may pave the way to solving the difficulties of the Muslim public in Israel, whereas non-participation in the parliamentary domain might leave a significant void that might be filled by non-Islamic parties. The aforementioned fatwa emphasizes that avoiding political action might cause the Muslim public to think that Islamists are concerned only with Muslim society - prepared to be involved only in matters of religion and responsible solely for the maintenance of proper Islamic practice.

\section{Conclusions}

To date, there seems to be no single locus of Islamic religious authority in Israel; multiple groups claim to speak on Islam's behalf. As such, there is religio-political fragmentation amid the Muslim community in Israel, each group seeking to create its own religious authority: CIS of the al-Qasemi Sufi Order; ICIF of NIM and, finally, the ad-hoc SIM ifta ' committees.

A survey of the work and methods of these Islamic religious agencies points to their similarities and differences regarding the situation of the Muslim minority in Israel. While the al-Qasemi Sufi Order and SIM demonstrate pragmatic approaches in their attempts to accommodate Israeli social culture and politics, NIM takes a much harder line, not only in its national political participation, but also with regard to the socio-cultural and theological issues addressed in its fatwas [43]. To date, none of these ifta' agencies in Israel has been able to formulate, authorize and apply a code of Islamic minority law in Israel, and they continue to rely heavily on foreign Islamic religious authorities. Israeli Muslims continue to maintain strong ties with the regional socio-cultural and religious space and with 
their peers in the Muslim-Arab world. Israeli ifta' agencies tend to adopt and adapt work methods used by foreign, regional Islamic religious authorities and to accept, as is, or adapt many of their opinions/decisions.

In its ongoing search for/and reliance on religious authorities and sources for rulings on mundane problems in daily life, the Islamic public regularly solicits religio-legal opinions from the international Muslim community (western Islamic minority law usually being inapplicable to the Israeli case). That is, the operating modes adopted by Muslims in the West, when dealing with their specific situations, seem to be impractical for use by the Muslim minority in Israel. The evolving Islamic law of minorities in Israel is much less developed than that in the West; therefore, at present, one cannot yet identify Islam in Israel as 'Israeli-Islam,' with its own unique nature, as in the case of 'Euro-Islam' in Europe. The Muslim minority in Israel is distinct from its western counterparts due to the essential differences in various sociocultural parameters including nationality, language, culture and ethnicity. In contrast to Muslim minorities in the West, the issues that concern the Muslim diaspora are mostly irrelevant to the Muslim-Israeli minority - because local Muslims are indigenous, living in the land of their birth, with their own collective historical narrative on the Holy Land (considered holy according to Muslim religious texts).

Even the assimilation of the Muslim minority in Israel is impractical, since the interest of the Jewish majority, as well as that of the Muslim minority, is to preserve their distinct identities. The IM in Israel, especially NIM, places the highest priority on the enhancement of Muslim religious identity. Finally, the nationalist conflict between Arabs and Jews, that produces suspicion and hostility between the two closely related ethnic groups, also has an impact on the nature of Islam in Israel that remains outside the purview of this article.

\section{References}

[1] Israeli Central Bureau of Statistics (ICBS), https://www.cbs.gov.il/en/Pages/default.aspx (last access, 10 November 2019).

[2] Ghanem, A. (2001). The Palestinian-Arab Minority in Israel, 1948-2000: A Political Study. New York: State University of New York Press, p. 124; Shafir, G., and Yoav P. (2002). Being Israeli: The Dynamics of Multiple Citizenship. Cambridge: Cambridge University Press, p. 111.

[3] Amara, M. (2003). "The Collective Identity of the Arabs in Israel in an Era of Peace," Israel Affairs 9, p. 255.

[4] On the Islamic resurgence in Israel, see Yvonne, H. (1992). "Islamists and the 'Problem of Israel': The 1967 Awakening," Middle East Journal 46 (2), pp. 266-85; Ali, E. H. D. "The Islamic Resurgence: Sources, Dynamics, and Implications," in Ali. E. H. D. ed. (1982), Islamic Resurgence in the Arab World New York: Praeger Publishers; Thomas, M. (1986). Islamic Resurgence among the Arabs in Israel (Givat Haviva: Arab Studies Institute; idem (1988). The Awakening of the Moslems in Israel. Givat Haviva: Institute for Arabic Studies
[Hebrew]; idem (1989), "The 'Muslim youth' in Israel," Hamizrah Hehadash 32, pp. 10-21 [Hebrew]; Rekhess, E. (1993), "Resurgent Islam in Israel," Asia and African Studies 27, pp. 189-206. On religious resurgence, see Eisenstadt, S. (2000), "The Resurgence of Religious Movements in Processes of Globalisation: Beyond End of History or Clash of Civilisations," International Journal on Multicultural Societies," 2 (1), pp. 4-15; Beckford, J. (2000), "Religious Movements and Globalization," in Cohen, R. and Rai, S. eds. (2000), Global Social Movements. London: Athlone Press; Hourani, M. (1991). "Tawba: Repentance among Israeli Moslem Arabs," Bamikhlala 2, pp. 102-10 [Hebrew]; Wuthnow, R. "World Order and Religious Movements," in Bergson, A., ed. (1980), Studies of the Modern World System. New York: Academic Press, pp. 57-75.

[5] See al-Haj M. (1988). "The Arab Internal Refugees in Israel: The Emergence of a Minority within the Minority," Immigration and Minorities 7 (2), pp. 149-65; idem, "The Sociopolitical Structure of the Arabs in Israel: External vs. Internal Orientation," in Hofman J. ed. (1988). Arab-Jewish Relations in Israel: A Quest of Human Understanding. Bristol, IN: Wyndham Hall, pp. 92-123; Smooha, S. (1988), "The Implication of Transition to Peace for Israeli Society," Annals of the American Academy of Political and Social Science 555, pp. 23-45; idem (1983), "Minority Responses in a Plural Society: A Typology of the Arabs in Israel," Sociology and Social Research 67 (4), pp. 436-56.

[6] Twentieth century ifta' was characterized by the emergence of the $h a y$ 'a, or 'fatwa committee', where more than one mufti ratifies the same fatwa. See Masud, M., Messick, B. \& Powers, D., eds. (1996). Islamic Legal Interpretation, Muftis and Their Fatwas. Cambridge, Mass.: Harvard University Press, pp. 3-32.

[7] See the websites of these institutions, at: http://www.isna.net; http://www.e-cfr.org/ar (last access, 10 November 2019).

[8] See Fishman, S. (2006). Fiqh al-Aqalliyyat: A Legal Theory for Muslim Minorities. Washington, D. C: Hudson Institute; Shavit, U. (2007). "Should Muslims Integrate into the West?" Middle East Quarterly 16 (4), pp. 13-21.

[9] See Zu bi, A. (2003). "The Khalawati Sufi Order in Palestine and Israel," M. A. Thesis. Haifa: Haifa University, pp. 31-54 [Hebrew]. On Sufi orders in modern times, see Van Bruinessen, M., and Day Howell J., eds., (2007). Sufism and the 'Modern' in Islam. London: I. B. Tauris; Raudvere C., and Stenberg, L., eds. (2009), Sufism Today: Heritage and Tradition in the Global Community. London: I. B. Tauris; Dressler, M., Geaves R. \& Klinkhammer G. eds. (2009), Sufis in Western Society: Global Networking and Locality. London: Routledge; De Jong F. (1983), "The Sufi Orders in Nineteenth and Twentieth Century Palestine," Studia Islamica 58, pp. 148-80; Weismann, I. (2004). "Sufi Brotherhoods in Syria and Israel: A Contemporary Overview," History of Religions 43, pp. 303-18.

[10] http://www.qsm.ac.il/pr/ (last access, 10 November 2019).

[11] Interview with Khaled Mahmud, 5 August 2015.

[12] http://fatawa.qsm.ac.il/m-04.htm (last access, 10 November 2019) [Arabic].

[13] http://fatawa.qsm.ac.il/m-07.htm (last access, 10 November 2019 [Arabic]; see also http://alqasimy.com/afta.php (last access, 10 November 2019 [Arabic]. 
[14] http://fatawa.qsm.ac.il/m-05.htm (last access, 10 November 2019 [Arabic]. On these principles, see al-Shatibi, I. (1969). al-Muwafaqat fi usul al-ahkam. 4 vols. Cairo: Maktabat Muhammad 'Ali Sbih, 3: 257; 4: 196, 198.

[15] Friedman R. (1973). "On the Concept of Authority in Political Philosophy," in Flathman R., ed. (1973), Concepts in Social and Political Philosophy. New York: Collier Macmillan, pp. 121-45.

[16] Harder, H. (2011). Sufism and Saint Veneration in Contemporary Bangladesh: The Maijbhandaris of Chittagong. London: Routledge, pp. 88-95.

[17] Mahmud, K. (2001). "The Ethical Behavior of the Sufi Disciple with his Sheikh in the Khalwati Order," in In the Footsteps of Sufism: History, Trends and Praxis: The First International Conference at al-Qasemi College. Baqa alGharbiyya, May 24-25, pp. 23-4.

[18] Mahmud, "The Ethical Behavior of the Sufi Disciple," 24.

[19] http://www.fatawah.com/Content-96 (last access, 10 November 2019) [Arabic].

[20] Ibid. See also Zahalka, I. (2018). The development of Islamic law in Israel. In Hatina, M. and al-Atawneh, M. eds. (2018), Muslims in the Jewish State. Tel Aviv: Hakibbutz Hameuchad, [Hebrew]. P. 6.

[21] http://www.pls48.net/?mod=articles\&ID=1148929\#.Vb8GcE1 WGJA (last access, 10 November 2019)[Arabic]; also http://www.fatawah.com/QuestionAdd.aspx (last access, 10 November 2019) [Arabic].

[22] http://www.fatawah.com/Content-961 (last access, 10 November 2019)[Arabic]; http://www.facebook.com/fatawah (last access, 10 November 2019) [Arabic].

[23] The latest multivolume edition was published in 2012. See Fatawa al-Majlis al-Islami li'l-ifta' (Umm al-Fahm: Mu'assasat al-Risala li'l-Nashr wa'l-I'lam, 2012). Also see the online Fatwa Bank at http://www.fatawah.com/Fatawah/0/0.aspx (last access, 10 November 2019) [Arabic].

[24] See ICIF's Q/A page at http://www.fatawah.com/Questions/0/0.aspx (last access, 10 November 2019)[Arabic]; Zahalka, "The Development of Islamic Jurisprudence in Israel," p. 6.

[25] http://www.fatawah.net/Articles/21.aspx (last access, 10 November 2019) [Arabic].

[26] In cases with multiple opinions, the murajjih (person who performs tarjih) usually compares those opinions with respect to their transmission, those who espouse them and their evidence.

[27] ICIF, Fatawa al-mar'a al-muslima (Umm al-Fahm: Mu'assasat al-Risala li'l-Nashr wa'l-I'lam, 2015), 6; see also http://www.fatawah.com/Content-96. On tarjih, see Hallaq, W. (2001). Authority, Continuity, and Change in Islamic Law. Cambridge: Cambridge University Press, pp. 127, 130-31; Abu Zahra, M. (1957), 'Usul al-figh. Cairo: Dar al-Fikr al-'Arabi, pp. 350-65; Weiss, B. (1978), "Interpretation in Islamic Law: The Theory of Ijtihad," American Journal of Comparative Law 26, pp. 199-212; idem (1992), The Search for God's Law: Islamic Jurisprudence in the Writings of Sayf al-Din al-Amidi. Salt Lake City: University of Utah Press.

[28] http://www.dar-
alifta.org/default.aspx?LangID\&Home $=1 \&$ LangID $=2 \quad$ (last access, $10 \quad$ February 2018); $\mathrm{http}: / / w w w . a l i f t a . n e t / D e f a u l t . a s p x$ ?languagename=en (last access, 10 February 2018).

[29] The Arabic term wasatiyya, literally 'centrist, middle, moderate path', stems from the Qur'anic verse, Q 2: 143: "And thus We have made you a community of moderation [wasat]." This verse suggests a lenient approach to the integration of opinions from almost all the Muslim schools-ofthought (madhhabs). Despite the widespread use of the term wasatiyya in modern Islamic discourse, there is still no precise and comprehensive definition of the term. Thus, one finds different renditions, such as 'middle path,' 'moderate way' or 'median course'. Recently, Muslim scholars have begun to address this matter. On wasatiyya in contemporary Arab and Muslim thought, see Browers, M. (2009), Political Ideology in the Arab World Accommodation and Transformation. Cambridge: Cambridge University Press; Polka, S. (2003). "The Centrist Stream in Egypt and Its Role in the Public Discourse Surrounding the Shaping of the Country's Cultural Identity," Middle Eastern Studies 39, pp. 39-64.

[30] http://www.fatawah.com/Fatawah/290.aspx?word (last access, 10 November 2019)[Arabic]. In Saudi Arabia, the Standing Committee for Scientific Research and Issuing Fatwas is responsible for conducting research and administering private ifta'. See al-Atawneh, M. (2010), Wahhabi Islam Facing the Challenges of Modernity: Dar al-Ifta'in Modern Saudi Arabia. Leiden: E. J. Brill, pp. 17-34; al-Dawish, A. (2000). Fatawa al-lajna al da'ima li'l-buhuth al-ilmiyya wa'l-ifta' wa'l-da'wa wa'l- irshad, 23 vols. Riyadh: Maktabat al'Ibikan; al-Shawadifi, S. (1991) Fatawa hay'at kibar al'ulama' bi'l-mamlaka al-'arabiyya al-sa'udiyya. Cairo: Maktabat al-Sunna.

[31] al-Atawneh. M. (2012), "Leisure and Entertainment (malahi) in Contemporary Islamic Legal Thought: Music and the Audio-Visual Media." Islamic Law and Society 19 (4), pp. 397-415.

[32] ICIF, Fatawa al-mar'a al-muslima, 76-79; al-Jaziri, A. (1999), al-Fiqh 'ala al-madhahib al-arba'a. Beirut: Dar alArqam, 4: 109-124.

[33] Ibid., 156. See the relevant fatwa at: http://fatwa.islamweb.net/fatwa/index.php?page=showfatwa\& Option=FatwaId \&Id=115965 (last access, 10 November 2019) [Arabic].

[34] ICIF, Fatawa al-mar'a al-muslima, 156.

[35] ICIF, Fatawa al-majlis al-Islami li' 'l-ifta' (Nazareth 2012), 2: 190-193.

[36] ICIF, Fatawa al-mar'a al-muslima, 145-146.

[37] See al-Jaziri, A. (1999). Al-Fiqh 'ala al-madhahib al-arba'a, 4: $109-20$

[38] http://www.islamweb.net/ver2/Fatwa/ShowFatwa.php?lang=A \&Option=FatwaId\&Id=14566 (last access, 10 November 2019) [Arabic].

[39] http://www.islamonline.net/servlet/Satellite?pagename=Islam Online-Arabic-

Ask Scholar/FatwaA/FatwaA\&cid $=1122528600856 \quad$ (last access, 10 November 2019) [Arabic].

[40] Al-Tirmidhi (1978). Sunan al-Tirmidhi. Cairo: Matba'at Mustafa al-Babi al-Halabi, 2: 462. 
[41] Interview with Hammad Abu Da'abis, 29 July 2015.

[42] Zahalka, I. (2018). "The Development of Islamic Law in Israel," in Hatina M. and al-Atawneh M. eds. (2018), Muslims in the Jewish State: Religion, Politics and Society. Tel Aviv: Hakibbutz Hameuchad [Hebrew].
[43] See Rekhess, E. (1991), "Fundamentalist Islam among Israeli Arabs," in Cohen K. ed. (1991), Perspectives in Israeli Pluralism. New York: Israeli Colloquium, pp. 34-44. 